\title{
Retention of organics and degradation of micropollutants in municipal wastewater using impregnated ceramics
}

\author{
Lev Tsapovsky ${ }^{1,2} \cdot$ Michal Simhon $^{1} \cdot$ Vincenzo Roberto Calderone $^{2} \cdot$ Gadi Rothenberg $^{2} \cdot$ Vitaly Gitis $^{2,3}(0)$
}

Received: 25 January 2019 / Accepted: 13 January 2020 / Published online: 22 January 2020

(c) The Author(s) 2020

\begin{abstract}
Pesticides, personal care products, industrial chemicals often pollute surface- and groundwater sources. With trace concentrations and low molecular weights, these micropollutants (MPs) easily penetrate through treatment systems and impose a real health threat on drinking water consumers. The absence of a dedicated MP-retaining treatment technology at water treatment plants results in a constant consumption of MP-contaminated water. Advanced oxidation processes, and in particular the Fenton reaction, can successfully degrade MPs if other, larger, fractions of organics are retained. Here, we suggest a novel combined two-stage retention-degradation approach. Ceramic membranes retain large organics such as bovine serum albumin (BSA). Fenton processes disintegrate nonretained MPs such as methylene blue (MB) and bisphenol A (BPA) that penetrate through the membrane. The efficiency of the suggested approach is high. Single-layered ultrafiltration membrane retains more than $96 \%$ BSA and degrades $40-50 \%$ of MB and BPA. The degree of degradation depends on both the impregnated metal oxide and the concentration of hydrogen peroxide. Vanadium-based catalysts retain more than $90 \%$ MPs but leach into permeate. Ferric oxides were the only stable catalysts that performed better in membranes than when impregnated on $\alpha-\mathrm{Al}_{2} \mathrm{O}_{3}$ pellets. A combined retention-degradation can be optimized to result in superior degree of retention. Catalytic ceramic membranes can retain large organic molecules and decompose MPs simultaneously. Three parameters affect the process efficiency: the dynamics of the influent fluid, the catalyst dose and the contact time.
\end{abstract}

\section{Graphic abstract}



Keywords Heterogeneous catalysis $\cdot \alpha-\mathrm{Al}_{2} \mathrm{O}_{3} \cdot$ Environment $\cdot$ Sustainability $\cdot$ Wastewater treatment plant

Gadi Rothenberg

g.rothenberg@uva.nl

Vitaly Gitis

gitis@bgu.ac.il

Extended author information available on the last page of the article 


\section{Introduction}

Trace organics such as pesticides, pharmaceuticals, personal care products and polymer additives are repeatedly found in surface- and groundwater sources (Ribeiro et al. 2015). The number of these so-called micropollutants (MPs) has grown alarmingly in the last two decades, from $<100$ to $>4000$ (Tixier et al. 2003). With concentrations ranging from a few $\mathrm{ng} / \mathrm{l}$ to $\mu \mathrm{g} / \mathrm{l}$ and easy penetration due to their low molecular weight (Matamoros and Bayona 2006), MPs can affect animal health. Examples include feminization and reproductive failure of male birds, reptiles and mammals (Colborn et al. 1994), shorter life spans in birds and mammals (Routledge et al. 1998) and endocrine disruption in fish and freshwater mussels (Tyler and Filby 2011). No relation between a consumption of specific MPs and human health problems has been reported yet (Darbre 2015; Christou et al. 2017). Nevertheless, the increasing amounts and numbers of MPs released into the environment are concerning, because their long-term effects on humans are unknown (Schwab et al. 2005; Stuart et al. 2012).

Micropollutants usually enter the environment via industrial, domestic and hospital wastewater, as well as via agricultural and aquaculture leachates (Tijani et al. 2015; Arkhangelsky et al. 2017). Today's wastewater treatment plants (WWTPs) have no MP-dedicated treatment (Luo et al. 2014). Many MPs are nonbiodegradable. In the absence of a dedicated treatment, they are released into the receiving water bodies and soon find their way back into drinking water sources (Song et al. 2007; Kleywegt et al. 2011). Tap water sources are treated at water treatment plants, but these do not retain MPs either. The entire cycle of environmental release, wastewater treatment and release, water uptake, water treatment, distribution and consumption has no single stage dedicated to MP retention. Our drinking water contains MPs, albeit at low concentrations (typically below $1 \mu \mathrm{g} / \mathrm{l}$ (Huerta-Fontela et al. 2011; Kleywegt et al. 2011) or as low as $10 \mathrm{ng} / \mathrm{l}$ (Heberer 2002). These concentrations will probably increase in the future due to ever wider use of MP-containing products and the widespread use of antibiotics (Zhang et al. 2008).

The problem is exacerbated in arid environments, where secondary effluents are increasingly used for irrigation. In principle, MPs can be eliminated from such effluents if dedicated treatments are applied. Promising technologies include adsorption on activated carbon (Sudhakaran et al. 2013), membrane filtration (Clara et al. 2005) and advanced oxidation processes AOPs (Zwiener and Frimmel 2000). The latter refers to reaction systems that generate highly reactive hydroxyl radicals $(\mathrm{OH} \cdot)$. Examples include $\left\{\mathrm{H}_{2} \mathrm{O}_{2} ; \mathrm{Fe}^{2+}\right\},\left\{\mathrm{TiO}_{2} ; \mathrm{h} v\right\},\left\{\mathrm{O}_{3} ; \mathrm{UV}\right\},\left\{\mathrm{O}_{3} ; \mathrm{H}_{2} \mathrm{O}_{2}\right\}$ and
$\left\{\mathrm{Mn}^{2+}\right.$; oxalic acid; $\left.\mathrm{O}_{3}\right\}$ (Fenton 1894; Andreozzi et al. 1999). The Fenton reaction in the first example takes place at ambient conditions and oxidizes organic compounds effectively using simple reaction setups (Kwan and Voelker 2003; Keenan and Sedlak 2008). Its disadvantage is the unselective characteristic of the radical attack in complex environments. For secondary WWTP effluents containing hundreds of non-MP organic compounds, most of the $\mathrm{OH}$. radicals would react with humic and fulvic acids and not with MPs (Malato et al. 2009).

Membrane filtration and AOP are often viewed as competitive technologies for MP retention, mainly because polymer membranes are prone to radical degradation. Ceramic membranes, however, behave differently due to the difference in chemical makeup (Gitis and Rothenberg 2016). Ceramic membranes typically contain pores larger than in polymer membranes and cannot effectively retain MPs. Here, we show that impregnating ceramic membranes with Fenton reagents creates a bifunctional system that can retain the organic matter and disintegrate MPs (Fig. 1). This is in effect a two-stage approach: In the first stage, an upper separation layer removes up to $95 \%$ of the organic matter from secondary effluents (e.g., humic and fulvic acids (Naim et al. 2014). Subsequently, those low molecular weight MPs that manage to squeeze through the membrane encounter a thin layer of Fenton catalyst that becomes reactive upon addition of hydrogen peroxide. The study examines the feasibility of the approach when the membrane is actively involved in the retention process. Previous reports use the membrane as a passive support for coating a catalyst layer (Horovitz et al. 2019).



Fig. 1 A scheme of a combined retention by ceramic membrane coupled with degradation by Fenton reagents 


\section{Materials and methods}

\section{Materials and instrumentation}

Ceramic membranes were made of $\alpha-\mathrm{Al}_{2} \mathrm{O}_{3}$ of two grain sizes. Grains of $0.85-1.00 \mu \mathrm{m}(99.98 \%$ purity, $3.0-4.0 \mathrm{~m}^{2} / \mathrm{g}$ surface area) and $0.35-0.49 \mu \mathrm{m}(99.95 \%$ purity, $7.0-9.0 \mathrm{~m}^{2} / \mathrm{g}$ surface area) were purchased from Alfa Aesar. Grains of $13 \mathrm{~nm} \gamma-\mathrm{Al}_{2} \mathrm{O}_{3}$ (99.8\% purity, $85-115 \mathrm{~m}^{2} / \mathrm{g}$ surface area) were purchased from SigmaAldrich. Polyacrylic acid sodium salt (PAA, $5100 \mathrm{Da}$, Sigma-Aldrich), potato starch (Sigma-Aldrich), silicon anti-foam (Sigma-Aldrich), vanadium chloride (Acros), copper chloride (Sigma-Aldrich), manganese chloride (Sigma-Aldrich), ferric chloride (Carlo Erba), bovine serum albumin (BSA, Sigma-Aldrich), methylene blue (MB, Sigma-Aldrich), bisphenol A (BPA, Sigma-Aldrich), hydrogen peroxide $\left(\mathrm{H}_{2} \mathrm{O}_{2}\right.$, Riedel de-Haen, $30 \%$ by weight in water), Bio-Rad protein assay (Bio-Rad) and gypsum powder (Tambur) were used as received. All ceramics were dried and sintered under air using a carbolite S30 2AU oven. Membrane imaging was done using a field emission scanning electron microscope (FI-SEM) JSM-7400F (JEOL). Unlike conventional SEM, FI-SEM can image the membranes directly, without the need for a conducting film coating. Top and side views were recorded at $3.1 \mathrm{kV}$. Side views were made using intentionally broken membranes. Cracking strengths were determined using the three-point test method on a Testometric M350-20CT instrument (Rondol Technology Ltd). Each membrane was laid on two constant horizontal balks and pressed by a moving twin balk upper arm. The pressure gradually increased up to the point when the membrane cracks, resulting in a sudden pressure drop. The accuracy of this measurement is better than $\pm 0.5 \%$. BPA concentrations were measured with GC-MS (Agilent 19091S-433) using a HP-5MS 5\% phenylmethylsiloxane column in a split mode with an initial oven temperature of $100{ }^{\circ} \mathrm{C}$, a maximal temperature of $325^{\circ} \mathrm{C}$, a heating ramp of $10{ }^{\circ} \mathrm{C} / \mathrm{min}$ and an initial flow of $1 \mathrm{ml} / \mathrm{min}$. Metal concentrations were measured with a Varian 720 ES ICP instrument. The concentration of MB was detected with UV-visible spectroscopy.

Figure 2 shows a schematic view of an experimental apparatus including the peristaltic pump, pressure gauges and flow meters. A cylindrical feed tank with a removable lid serves for a feed supply and for a retentate collection. The feed is delivered to a filtration cell by a high-pressure pump. There is a valve in the retentate line that allows the outlet pressure, and thus the TMP, to be controlled. The membrane permeate flux is determined gravimetrically by periodic collection of permeate into beakers. Flow meter on a retentate line gives an indication of a retentate flow. The cell is made of stainless steel and was operated in a dead-end mode, with magnetic stirring.(Arkhangelsky et al. 2008). The hydrogen peroxide is delivered to a permeate by a peristaltic pump.

\section{Procedure for impregnation of ceramic pellets}

Pre-sintered $\alpha-\mathrm{Al}_{2} \mathrm{O}_{3}$ pellets ( $5 \mathrm{wt} \%$ ) were added to a solution containing $0.8 \mathrm{ppm} \mathrm{Mn}^{2+}, \mathrm{Vn}^{3+}, \mathrm{Fe}^{3+}, \mathrm{Cu}^{2+}$ ions or mole/mole mixtures of $2: 1 \mathrm{Fe}^{3+} / \mathrm{Cu}^{2+}, 2: 1 \mathrm{Fe}^{3+} / \mathrm{Mn}^{2+}, 1: 1$ $\mathrm{Vn}^{3+} / \mathrm{Fe}^{3+}, 2: 1 \mathrm{Vn}^{3+} / \mathrm{Mn}^{2+}, 1: 1 \mathrm{Vn}^{3+} / \mathrm{Cu}^{2+}$, in $8 \mathrm{ml}$ deionized water (DIW). The suspension was heated to $40{ }^{\circ} \mathrm{C}$ and

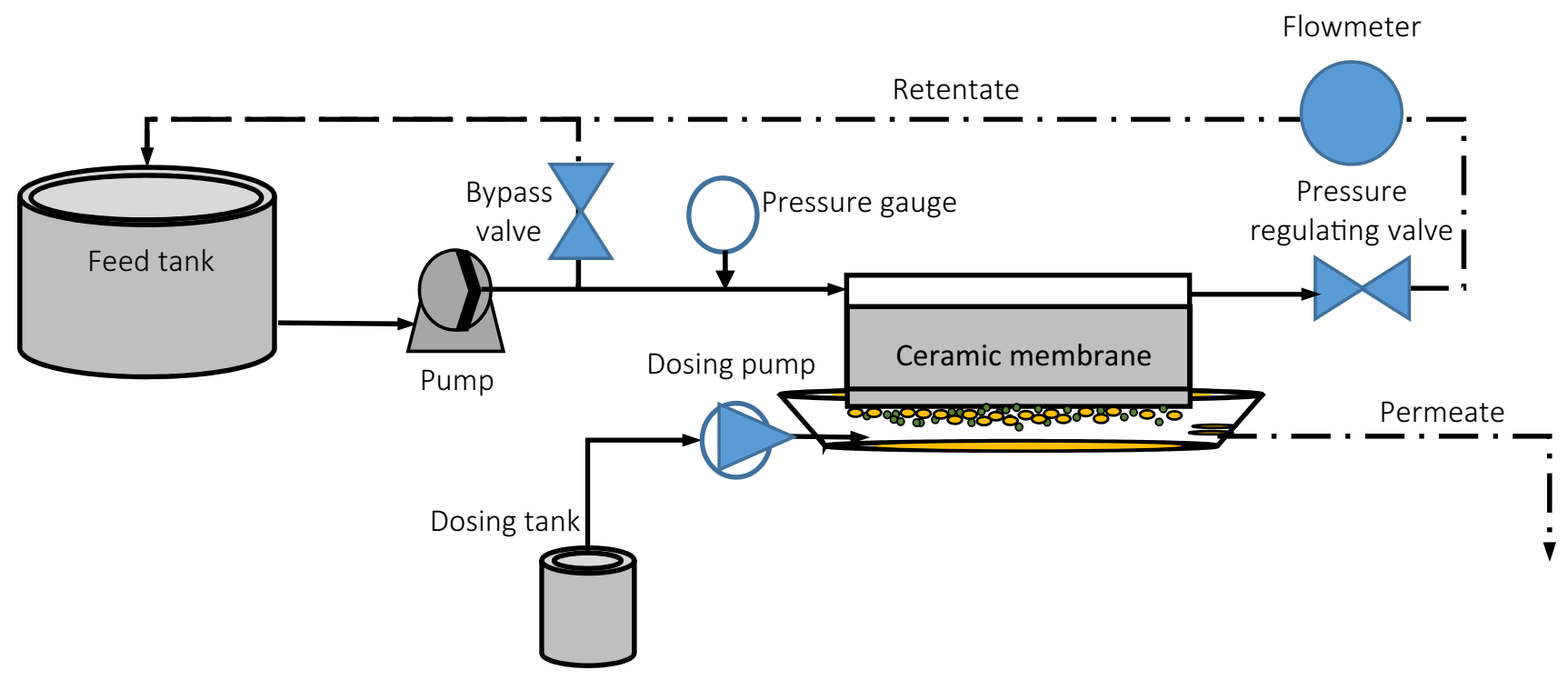

Fig. 2 Schematic view of ultrafiltration setup 
magnetically stirred for $12 \mathrm{~h}$ until all water evaporated. The impregnated pellets were ground, dried at room temperature for $5 \mathrm{~h}$ and calcined at $500{ }^{\circ} \mathrm{C}$ for $2 \mathrm{~h}$ using $20^{\circ} \mathrm{C} / \mathrm{min}$ and $10{ }^{\circ} \mathrm{C} / \mathrm{min}$ heating and cooling ramps, respectively. The best combinations were later implemented for membrane impregnations.

\section{Procedure for preparation of impregnated ceramic membranes}

Ceramic membranes were prepared by addition of $9.1 \mathrm{~g}$ $\alpha-\mathrm{Al}_{2} \mathrm{O}_{3}$ grains and $40 \mu \mathrm{l}$ silicon anti-foam into an initial solution made of $0.065 \mathrm{~g}(0.5 \mathrm{wt} \%)$ PAA dispersant in $3.9 \mathrm{ml}$ DIW. The slurry was magnetically stirred for $6 \mathrm{~h}$ and poured into 41.5-mm-inner-diameter Teflon molds custommade at the University of Amsterdam mechanical workshop. A green body with a disk shape and $13 \mathrm{~g}$ total weight was obtained after $48 \mathrm{~h}$ drying in open air. A thermolysis (Gitis and Rothenberg 2016) was performed for $10 \mathrm{~h}$ at $100{ }^{\circ} \mathrm{C}$. The sintering was performed for 4,6 or $8 \mathrm{~h}$ at 1100,1200 , 1300 or $1400{ }^{\circ} \mathrm{C}$ using $2{ }^{\circ} \mathrm{C} / \mathrm{min}$ and $5{ }^{\circ} \mathrm{C} / \mathrm{min}$ heating and cooling ramps, respectively. Sintered membranes were polished on a rotating wheel coated with silicon carbide GRIT 4000 sand paper (Buehler Ltd.). The membranes were held inside stainless steel molds, and the sanding paper was wetted periodically. The polished membranes were washed with DIW. Additional DIW wash was performed inside the filtration cell by forcing $150 \mathrm{ml}$ DIW through the membrane at 1 bar transmembrane pressure. The impregnation was performed by an immersion of membranes into a solution that contained 10,30 or $100 \mathrm{mM}$ of $\mathrm{Mn}^{2+}, \mathrm{Vn}^{3+}, \mathrm{Fe}^{3+}, \mathrm{Cu}^{2+}$ ions, or their $1: 1 \mathrm{Vn}^{3+} / \mathrm{Fe}^{3+}$ and $\mathrm{Vn}^{3+} / \mathrm{Cu}^{2+}$ combinations, dissolved in $50 \mathrm{ml}$ DIW. Impregnation was performed in closed beakers at room temperature and without stirring for $16 \mathrm{~h}$. The thermolysis was performed for $5 \mathrm{~h}$ at $100{ }^{\circ} \mathrm{C}$, and calcination was performed at $500{ }^{\circ} \mathrm{C}$ for $2 \mathrm{~h}$ with $20^{\circ} \mathrm{C} / \mathrm{min}$ and $10{ }^{\circ} \mathrm{C} / \mathrm{min}$ heating and cooling ramps, respectively.

\section{Procedure for detection and quantification of BSA}

Municipal wastewater treatment includes biological degradation, such that the secondary effluents contain dissolved organic macromolecules including proteins, polysaccharides, amino-sugars, acids, humic and fulvic acids and cell components (Naim et al. 2012; Levitsky et al. 2014). A bovine serum albumin (BSA) represented these macromolecules in the study. The BSA concentration was assessed with BioRad protein assay solution and a Novaspec 3 Healthcare Bio-Sciences AB spectrophotometer at $595 \mathrm{~nm}$ wavelength. The calibration curve was plotted on six points using 2,4 , $6,8,10,12$ ppm BSA. The measurements were performed with $1 \mathrm{ml}$ total volume at 1/1/3 BSA/Bio-Rad/DIW dilutions following the recommendations in Bio-Rad manual. The Bio-Rad protein assay lower detection limit is $2 \mathrm{ppm}$.

\section{Procedure for retention and catalytic decomposition experiments}

The efficiency of a Fenton-catalyzed decomposition was quantified with methylene blue $\left(\mathrm{C}_{16} \mathrm{H}_{18} \mathrm{~N}_{3} \mathrm{SCl}\right)$ and with bisphenol-A. Methylene blue (MB) is the most common dye in effluents of textile, paper and printing industries. Bisphenol A (BPA) affects growth, reproduction and development of aquatic organisms. Among freshwater organisms, fish is the most sensitive and the most affected species. BPA is linked to endocrine disordered obesity in animals and hormone-induced premature puberty in young women (Luo et al. 2014). Screening experiments were performed with $5 \mathrm{mg}$ MB dissolved in $500 \mathrm{ml}$ DIW. Samples were reacted with $14,18,35,140,180,350,1400,1800$ or $3500 \mathrm{ppm}$ $\mathrm{H}_{2} \mathrm{O}_{2}$ in the presence of a catalyst. The MB adsorption at $664 \mathrm{~nm}$ was recorded with Cary 50 Bio Spectrophotometer (Varian) 1 min after an addition of a catalyst and $\mathrm{H}_{2} \mathrm{O}_{2}$. Each sample was filtered $(0.45 \mu \mathrm{m})$ prior to measurement. The spectra recording time of 1 min was optimized in a set of control experiments.

Filtration experiments were performed at 0.5 and $1.0 \mathrm{bar}$ transmembrane pressure (TMP) with $10 \mathrm{ppm} \mathrm{MB,} 10 \mathrm{ppm}$ BPA, and $35 \mathrm{ppm} \mathrm{H}_{2} \mathrm{O}_{2}$. Permeate aliquots of 10,15 and $20 \mathrm{ml}$ were collected for the permeate flux, MP and BPA analysis. The TMP values were chosen to secure a recommended range of transmembrane fluxes in secondary effluent filtration. The range is between 30 and $40 \mathrm{LMH}$.

\section{Results and discussion}

\section{Optimizing the ceramic membranes' preparation parameters}

To ensure full control over the membrane preparation process, the ceramic membranes were prepared in-house (see details in the experimental section). While dozens of preparation process variables exist (Gitis and Rothenberg 2016), the most critical parameters were found through control experiments to be binder concentration, sintering temperature, holding time and the quantity of mixed powder. Optimizing these four parameters yielded membranes that displayed effective membrane permeate flux and a high mechanical strength. The strength is usually increased by decreasing the total pore volume and the connected porosity. Membrane with high mechanical strength has less pores able to pass liquids, i.e., has low membrane permeate flux. 
The mechanical strength was tested by cracking strength at break (Gitis and Rothenberg 2016).

\section{Binder concentration}

Figure $3 \mathrm{a}$ shows the changes in permeate flux and in cracking strength at break of the ceramic membranes as a function of the starch binder content. Starch is a popular binder for aqueous suspensions (Lyckfeldt and Ferreira 1998) that decomposes later than any other additive, leaving channels that change their form and dimensions during sintering (Lindqvist and Lidén 1997). Elimination of the channels results in membrane with superior mechanical strength and with no permeate flux. Thus, the starch concentration should be relatively low to prevent cracking, yet high enough to ensure significant permeate flux. Experiments were run with $0,3,7$ and $10 \mathrm{wt} \%$ starch. Higher concentrations of binder typically broaden the pore size distribution (Yang et al. 1996), promoting particle agglomeration in the slurry and the formation of closed pores (Kritikaki and Tsetsekou


Fig. 3 Changes in permeate flux (diamonds) and mechanical strength at break (squares) as a function of a starch content: sintering at $1200{ }^{\circ} \mathrm{C}$, holding time $6 \mathrm{~h}$, b sintering temperature and binder content (empty shapes no binder, full shapes $7 \%$ binder): $6 \mathrm{~h}$ holding time, $\mathbf{c}$ holding time and binder content (empty shapes no binder, full

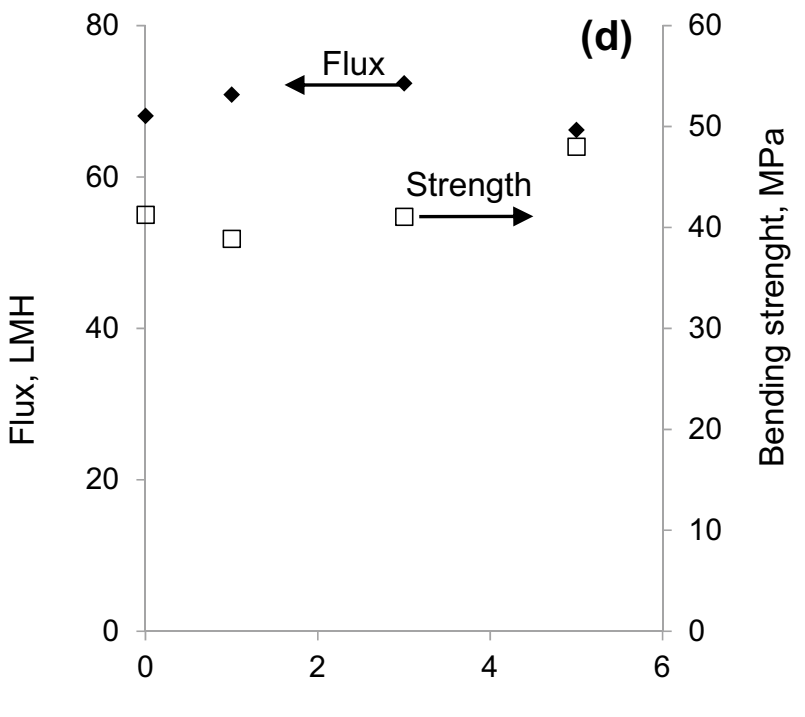

$\% \mathrm{w} / \mathrm{w}$ of $13 \mathrm{~nm}$ alumina in total powder

shapes $7 \%$ binder): sintering at $1200{ }^{\circ} \mathrm{C}$, d $0.013 / 0.85 \mathrm{~mm} \alpha-\mathrm{Al}_{2} \mathrm{O}_{3}$ particle ratio: sintering at $1200{ }^{\circ} \mathrm{C}$, holding time $6 \mathrm{~h}$, no binder. All membranes were sintered with $2{ }^{\circ} \mathrm{C} / \mathrm{min}$ heating and $5{ }^{\circ} \mathrm{C} / \mathrm{min}$ cooling ramp protocol. Permeate flux was measured with DIW at room temperature and 1 bar TMP 
2009). Adding more binder increased the permeate flux and lowered the mechanical strength. Sintering with no starch yielded membranes with $68 \mathrm{l} / \mathrm{m}^{2} \mathrm{~h}(\mathrm{LMH})$ flux and $40 \mathrm{MPa}$ mechanical strength. Using $7 \mathrm{wt} \%$ starch yielded membranes with $160 \mathrm{LMH}$ flux but $<10 \mathrm{MPa}$ mechanical strength. Therefore, $3 \mathrm{wt} \%$ starch was opted for yielding a permeate flux of $97 \mathrm{LMH}$ and a mechanical strength of $30 \mathrm{MPa}$. Typical flux of DIW through membrane supports should be higher than $70 \mathrm{LMH}$, and that was the starting point in the optimization of the binder concentration.

\section{Sintering temperature}

The corresponding changes in permeate flux and mechanical strength as a function of sintering temperature are shown in Fig. 3b. Sintering is the most influential stage in the preparation of ceramic membranes, and the sintering temperature is the most important variable. In general, sintering at high temperatures promotes densification and depresses coarsening but also increases the production cost (Gitis and Rothenberg 2016). Denser membranes are less porous, with smaller pores. This results in superior mechanical strength and low permeate flux. Lowering the sintering temperature generates membranes with high porosity and low mechanical strength. Given that the ideal membrane should have both a high mechanical strength and a high permeate flux, the optimal sintering temperature is a trade-off between the two. Sintering was performed at $1100,1200,1300$ and $1400{ }^{\circ} \mathrm{C}$. Sintering at $1100{ }^{\circ} \mathrm{C}$ resulted in a membrane with $140 \mathrm{LMH}$ but $<10 \mathrm{MPa}$ mechanical strength. Sintering at $1400^{\circ} \mathrm{C}$ produced membranes with $>200$ MPa mechanical strength but only $40 \mathrm{LMH}$ permeate flux. The optimum was found at $1200{ }^{\circ} \mathrm{C}$ with $30 \mathrm{MPa}$ and $97 \mathrm{LMH}$. The typical DIW flux through membrane supports should be higher than $70 \mathrm{LMH}$, and that was the starting point in the optimization of sintering temperature.

\section{Holding time}

Figure $3 \mathrm{c}$ shows the changes in permeate flux and mechanical strength as a function of the holding time. The sintering is often performed with a gradual increase in temperature. If the increase rate is high, the sintering process continues past the ramping, and the membrane is held at its sintering temperature for a holding time. Short holding times reduce the total processing time and energy consumption. Conversely, long holding times increase membrane densification and mechanical strength but lower the permeate flux. A $150 \mathrm{LMH}$ and $10 \mathrm{MPa}$ were measured at $4 \mathrm{~h}$ holding time with $7 \mathrm{wt} \%$ binder. After an $8 \mathrm{~h}$ holding time, the permeate flux decreased to $120 \mathrm{LMH}$ and the mechanical strength increased above $20 \mathrm{MPa}$. The optimum was found using a $6 \mathrm{~h}$ holding time with $3 \mathrm{wt} \%$ binder, resulting in a flux of 97
LMH and a mechanical strength of $30 \mathrm{MPa}$. Typical DIW flux through membrane supports should be higher than 70 $\mathrm{LMH}$, and that was the starting point in the optimization of the holding time.

\section{Mixing different particles}

A dense packing of particles in the initial slurry increases mechanical strength and decreases membrane permeability. A paste with higher density is less likely to shrink during sintering. The packing density is defined as a dimensionless ratio of the particle fraction to the total slurry. An ordered packing with equal spherical particles can reach a packing density value of 0.74 . Higher packing densities can be achieved by preparing the initial slurry from a mixed powder containing more than one grain size (Kritikaki and Tsetsekou 2009). There is no standard or typical ratio of large/ small grains. Through this work, it was observed that mixing different particles had a small negative effect on the permeate flux and a significant positive effect on the mechanical strength. Adding $1 \mathrm{wt} \%$ of $13 \mathrm{~nm}$ particles into a powder of $0.85-1.0 \mu \mathrm{m} \alpha-\mathrm{Al}_{2} \mathrm{O}_{3}$ increased the mechanical strength by $16 \%$ and decreased the flux by only $3 \%$. Similarly, adding $3 \mathrm{wt} \%$ increased the mechanical strength by $44 \%$ and decreased the flux by $6 \%$.

FI-SEM was used to examine the membrane integrity, grain size and pore size (Wyart et al. 2008). Figure 4a, b shows front and side views of an intact ceramic membrane with grain sizes ranging between 1 and $2 \mu \mathrm{m}$. A wider grain size distribution with grains $<10 \mathrm{~nm}$ is seen in Fig. $4 \mathrm{c}$, showing a membrane made from a dual $13 \mathrm{~nm} / 0.85 \mu \mathrm{m}$ $\alpha-\mathrm{Al}_{2} \mathrm{O}_{3}$ grain mixture (see the experimental section for details). Impregnating the membrane with iron oxide did not change the structure visibly (Fig. 4d).

\section{Fenton reactions catalyzed by metal-oxide-impregnated $\mathrm{a}-\mathrm{Al}_{2} \mathrm{O}_{3}$ particles}

In a typical reaction, artificial wastewater feed containing either $10 \mathrm{ppm}$ of methylene blue (MB) or $10 \mathrm{ppm}$ of bisphenol A (BPA) and $35 \mathrm{ml} \mathrm{H}_{2} \mathrm{O}_{2}$ was pushed through the membrane at 0.5 and 1.0 bar TMP. First, a set of experiments were run with magnetite, which is a known Fenton catalyst (Zhang et al. 2009). Figure 5 shows the efficiency of MB degradation with addition of 14, 35, 140, 350 and $1400 \mathrm{ppm}$ $\mathrm{H}_{2} \mathrm{O}_{2}$, in the presence of either $0.8 \mathrm{ppm}$ (Fig. $5 \mathrm{a}$ ) or $8.0 \mathrm{ppm}$ (Fig. 5b) magnetite. MB decomposes in the presence of $\mathrm{OH}$. radicals. Possible reaction mechanisms discussed by Oliveira et al. (2011) include a hydroxyl attack on one or two aromatic MB rings, formation of aliphatic intermediate and finally a full conversion into carbon dioxide and water. Control experiments without catalyst showed $<4 \%$ degradation. In the presence of magnetite, $93 \%$ degradation was 

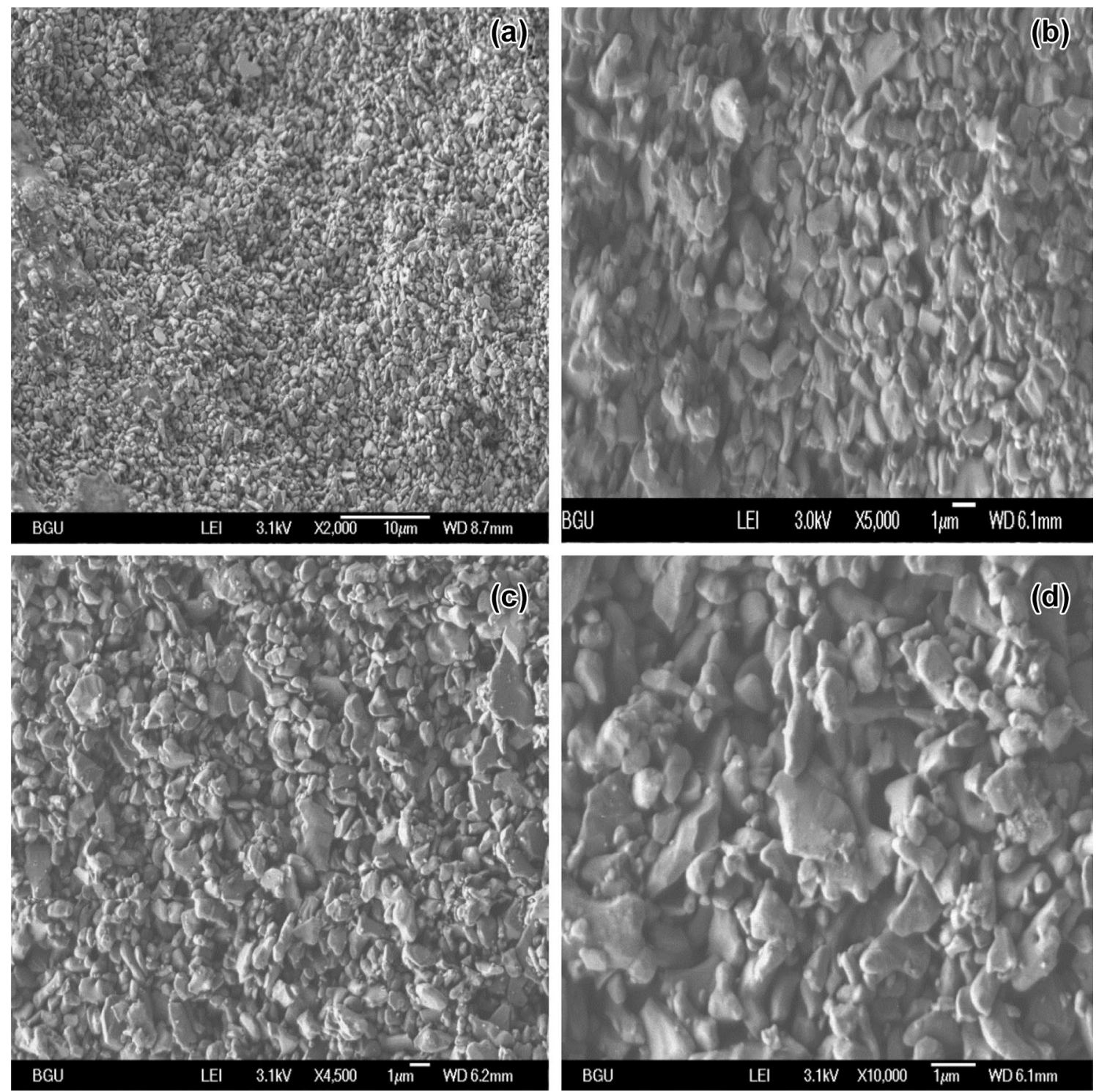

Fig. 4 Scanning electron micrographs of ceramic membranes with a top view (a), side view (b), dual $13 \mathrm{~nm} / 0.85 \mu \mathrm{m}$ load of $\alpha-\mathrm{Al}_{2} \mathrm{O}_{3}$ grains (c), impregnated with Fe oxide (d)

achieved after $12 \mathrm{~min}$. The MB degradation with low catalyst coverage improved with time and depended on $\mathrm{H}_{2} \mathrm{O}_{2}$ concentration. The $97 \%$ degradation with $8 \mathrm{ppm}$ magnetite was independent of the contact time and/or $\mathrm{H}_{2} \mathrm{O}_{2}$ concentration. Note that the reported average $\mathrm{OH}$. generation rate of $10^{9}-10^{10} \mathrm{dm}^{3} / \mathrm{mol}-\mathrm{s}$ means that nearly all the MB would degrade after just 1 min if sufficient catalyst surface is available (Buxton et al. 1988).

Several other oxide catalysts were then tested. Figure $5 \mathrm{c}$ shows the $\mathrm{MB}$ degradation with $\mathrm{Fe}_{2} \mathrm{O}_{3}, \mathrm{CuO}, \mathrm{MnO}$, $\mathrm{Fe}_{2} \mathrm{MnO}_{3}$ and $\mathrm{Fe}_{2} \mathrm{CuO}_{4}$. The average degradation was $<20 \%$ for both low and high catalyst loadings. Impregnating with vanadium oxide and vanadium oxide complexes was much more successful (Fig. 5d), yielding $>90 \%$ degradation with
$8 \mathrm{ppm}$ catalyst loading. The high efficiency of vanadium oxides in generation of $\mathrm{OH} \cdot$ radicals is well known (Mizuno and Kamata 2011). The challenge of vanadium leaching and possible homogeneous catalysis is also well known (Arends and Sheldon 2001), although not from $\alpha-\mathrm{Al}_{2} \mathrm{O}_{3}$ grains. Based on this information, it was decided to proceed with a combined membrane + catalyst stage with vanadium oxide and discover the leaching challenge in parallel.

\section{Combined BSA retention and BPA degradation using catalytic ceramic membranes}

The combination of the retention of a representative protein bovine serum albumin BSA and degradation of bisphenol A 



Fig. 5 Degradation of methylene blue (MB) with $0.8 \mathrm{ppm}$ (a) and $8 \mathrm{ppm}$ (b) magnetite in the presence of 14 (diamond), 35 (square), 140 (triangle), 350 (empty diamonds) and 1400 (empty squares) ppm hydrogen peroxide. Ten ppm initial MB solution, room temperature. The reaction starts with addition of $\mathrm{H}_{2} \mathrm{O}_{2}$ and a catalyst, and the first

(BPA) was then examined. First, a set of retention-degradation experiments were run with the custom-made ceramic membranes impregnated with vanadium oxide (Fig. 6a). Membranes impregnated with 2, 6 and $20 \mathrm{M}$ vanadium out of $\mathrm{V}_{2} \mathrm{O}_{3}$ dissolved in DIW were tested. Each membrane was tested at three $\mathrm{H}_{2} \mathrm{O}_{2}$ concentrations: 35,350 and $3500 \mathrm{ppm}$. Control experiments with no catalyst yielded $<5 \%$ BPA degradation. The samples containing vanadium showed various results, ranging from $30 \%$ BPA degradation for low $\mathrm{V} /$ low $\mathrm{H}_{2} \mathrm{O}_{2}$, up to $77 \%$ with high $\mathrm{V} /$ high $\mathrm{H}_{2} \mathrm{O}_{2}$ levels. Unfortunately, vanadium species did leach into the permeate (Table 1). There is a clear correlation between the vanadium concentration in the impregnation solution and the $\mathrm{H}_{2} \mathrm{O}_{2}$


measurement is taken at $1 \mathrm{~min}$ to minimize a possible bias from start/ sampling time proximity. Degradation of $\mathrm{MB}$ by 0.8 and $8 \mathrm{ppm} \mathrm{MnO}$ (empty squares), $\mathrm{CuO}$ (diamonds), and $\mathrm{Fe}_{2} \mathrm{O}_{3}$ (empty circles) (c), and by $\mathrm{Fe}_{2} \mathrm{MnO}_{4}, \mathrm{Fe}_{2} \mathrm{CuO}_{4}, \mathrm{~V}_{2} \mathrm{O}_{3}$, V/Fe 1:1, V/Mn 2:1, V/Cu 2:1 (d) catalysts impregnated on $\alpha-\mathrm{Al}_{2} \mathrm{O}_{3}$ particles

concentration. Minimal vanadium leaching was found from a membrane that was impregnated in a $2 \mathrm{M} \mathrm{V}$ solution and exposed to $35 \mathrm{ppm} \mathrm{H}_{2} \mathrm{O}_{2}$. The highest leaching was observed from membranes impregnated with $20 \mathrm{M} \mathrm{V}$ solution and exposed to $3500 \mathrm{ppm}_{2} \mathrm{O}_{2}$.

Figure $6 \mathrm{~b}$ shows the degree of BPA and MB degradation by membranes impregnated with $\mathrm{Fe}_{2} \mathrm{O}_{3}, \mathrm{CuO}, \mathrm{V}_{2} \mathrm{O}_{3}, \mathrm{~V} / \mathrm{Fe}$ $1: 1$ and $\mathrm{V} / \mathrm{Cu} 1: 1$. These vanadium-impregnated membranes decomposed between 48 and 53\% BPA. That level was considered sufficient for the first set of experiments, albeit that significant vanadium leaching was observed (Table 1).

To tackle the leaching challenge, the vanadium was incorporated into the membranes during the green body 




Fig. 6 Degradation of bisphenol A (BPA) with $2 \mathrm{M}, 6 \mathrm{M}$ and $20 \mathrm{M} \mathrm{V}$ in $\mathrm{V}_{2} \mathrm{O}_{3}$ solution impregnated on a ceramic membrane (a). Degradation of BPA and methylene blue (MB) with $\mathrm{Fe}_{2} \mathrm{O}_{3}, \mathrm{CuO}, \mathrm{V}_{2} \mathrm{O}_{3}, \mathrm{~V}: \mathrm{Fe}$ 1:1 and $\mathrm{V}: \mathrm{Cu}$ 2:1 impregnated on a ceramic membrane (b). Initial



BPA concentration and BSA concentrations are $50 \mathrm{ppm}$. Initial MB concentration is $10 \mathrm{ppm}$. Filtration experiments were performed at 1 bar TMP with pure $\mathrm{N}_{2}$ and at room temperature
Table 1 Concentration of vanadium ions in the permeate

\begin{tabular}{lllll}
\hline Entry & Impregnating solution & Leaching, ppm & $\begin{array}{l}\text { BSA reten- } \\
\text { tion, } \%\end{array}$ & BPA degradation, \% \\
\hline 1 & $2 \mathrm{M} \mathrm{V}$ & $8.4\left(2.6^{*} ; 25.0^{* *}\right) \mathrm{V}$ & $>96$ & $33.4\left(24.9^{*} ; 35.3^{* *}\right)$ \\
2 & $6 \mathrm{M} \mathrm{V}$ & $7.9\left(3.5^{*} ; 53.0^{* *}\right) \mathrm{V}$ & $>96$ & $24.7\left(47.8^{*} ; 53.1^{* *}\right)$ \\
3 & $20 \mathrm{M}$ & $6.3\left(24.0^{*} ; 135.0^{* *}\right) \mathrm{V}$ & $>96$ & $48.8\left(40.1^{*} ; 80.6^{* *}\right)$ \\
4 & $20 \mathrm{M} \mathrm{V}: \mathrm{Fe} 1: 1$ & $19.3 \mathrm{~V}$ & $>96$ & 45 \\
5 & $20 \mathrm{M} \mathrm{V:Cu} \mathrm{1:1}$ & $6.9 \mathrm{~V}$ & $>96$ & 43 \\
6 & $20 \mathrm{M} \mathrm{CuO}$ & $4.3 \mathrm{Cu}$ & $>96$ & 17 \\
7 & $20 \mathrm{M} \mathrm{Fe}_{2} \mathrm{O}_{3}$ & - & $>96$ & 16 \\
\hline
\end{tabular}

Reaction conditions: Initial BPA and BSA concentrations are 50 ppm. 350 ppm $\mathrm{H}_{2} \mathrm{O}_{2}$. Catalytic membrane experiments were performed at 1 bar transmembrane pressure (TMP) with pure $\mathrm{N}_{2}$ and at room temperature

*Reactions in the presence of $35 \mathrm{ppm} \mathrm{H}_{2} \mathrm{O}_{2}$

**Reactions in the presence of $3500 \mathrm{ppm} \mathrm{H}_{2} \mathrm{O}_{2}$

formation step. Control experiments showed that the optimal vanadium concentration was $2 \mathrm{M}$ V. Higher concentration made the slurry very viscous and impossible to manage, probably due to ceramic particles destabilization, eventually leading to cracking during sintering. The V-embedded


and $7 \%$ of BPA with $35 \mathrm{ppm}_{2} \mathrm{O}_{2}$. Their average permeate flux was $112 \mathrm{LMH}, 65 \%$ higher than the flux of similar membranes without vanadium addition. It should be noted that these membranes did not leach any vanadium into the permeate. Despite that, the experiments with vanadium were halt. Vanadium leaches in acid environment or performs insufficiently being embedded in the green body. The leaching is due to increase in the valence of $\mathrm{V}$ in vanadium oxide that increases the vanadium solubility (Szymczycha-Madeja 2011), or due to a weak link between the vanadium oxide and a membrane surface (Li et al. 2014). Ferrous and ferric oxides are the preferred catalysts for the application.

The membranes impregnated with $\mathrm{Fe}_{2} \mathrm{O}_{3}$ and $\mathrm{CuO}$ yielded $16 \%$ of BPA decomposition. This value increased to $33 \%$ with $\mathrm{Fe}_{2} \mathrm{O}_{3}$-impregnated membranes when the experiments were run at 0.5 bar TMP due to longer contact times (data not shown). The MB decomposition with $\mathrm{Fe}_{2} \mathrm{O}_{3^{-}}$and $\mathrm{CuO}$-impregnated membranes was $39 \%$ 
and $54 \%$ of BPA, respectively, while $\mathrm{V}-, \mathrm{V} / \mathrm{Fe}-$ and $\mathrm{V} /$ $\mathrm{Cu}$-impregnated membranes yielded $30-40 \%$ of BPA decomposition.

The retention of bovine serum albumin (BSA) was then tested on different impregnated membranes. BSA is often used as a model protein for municipal wastewater streams that contain biomolecules. Four different types of membranes were tested. All demonstrated retention levels $>96 \%$ (the actual retention level could be even higher, as the minimum detection level of the Bio-Rad kit of $2 \mathrm{ppm}$ was reached). The lowest retention of $94 \%$ was found at first $5 \mathrm{ml}$ of permeate through membranes prepared from 0.85 to $1 \mu \mathrm{m}$ and 2:1 0.85-1:0.35-0.49 $\mu \mathrm{m}$ grains.

\section{Conclusions}

Catalytic ceramic membranes can retain large organic molecules and decompose micropollutants simultaneously. The bovine serum albumin (BSA) was used as a representative organic macromolecule found in municipal wastewater. The BSA retention level of one-layered simple ceramic membranes was above $96 \%$, as high as the BSA detection limit. Moreover, ceramic membranes can be impregnated with metal oxides and decompose up to $40-50 \%$ of micropollutants such as bisphenol A (BPA) and methylene blue (MB). The decomposition occurs in the presence of hydrogen peroxide due to Fenton reaction. The degradation by impregnated membranes is lower than the degradation by impregnated pellets but can be increased by increasing the contact time.

Three parameters affect the process efficiency: the dynamics of the influent fluid, the catalyst dose and the contact time. The main drawback of this approach is the potential leaching of catalyst into this highly reactive environment due to poor membrane/catalyst bonding. Nevertheless, the combined separation degradation method reported here compares well on price/quality ratios when compared to the combinations of ceramic membranes with ozone (Karnik et al. 2005; Zhu et al. 2011) and UV irradiation (Al-Bastaki 2004). The key for its full implementation is a thorough investigation of potential combinations of catalysts and $\mathrm{H}_{2} \mathrm{O}_{2}$ doses that can effectively disintegrate the pollutant but not harm the catalyst-membrane bond.

\section{Compliance with ethical standards}

Conflict of interest The authors declare that they have no conflict of interest.
Open Access This article is licensed under a Creative Commons Attribution 4.0 International License, which permits use, sharing, adaptation, distribution and reproduction in any medium or format, as long as you give appropriate credit to the original author(s) and the source, provide a link to the Creative Commons licence, and indicate if changes were made. The images or other third party material in this article are included in the article's Creative Commons licence, unless indicated otherwise in a credit line to the material. If material is not included in the article's Creative Commons licence and your intended use is not permitted by statutory regulation or exceeds the permitted use, you will need to obtain permission directly from the copyright holder. To view a copy of this licence, visit http://creativecommons.org/licenses/by/4.0/.

\section{References}

Al-Bastaki NM (2004) Performance of advanced methods for treatment of wastewater: UV/TiO2, RO and UF. Chem Eng Process Process Intensif 43:935-940

Andreozzi R, Caprio V, Insola A, Marotta R (1999) Advanced oxidation processes (AOP) for water purification and recovery. Catal Today 53:51-59

Arends IWCE, Sheldon RA (2001) Activities and stabilities of heterogeneous catalysts in selective liquid phase oxidations: recent developments. Catal Deactiv 212:175-187

Arkhangelsky E, Steubing B, Ben-Dov E, et al (2008) Influence of $\mathrm{pH}$ and ionic strength on transmission of plasmid DNA through ultrafiltration membranes. In: Issue 1 First Oxf Nottm Water Membr Res Event 2-4 July 2006 Oxf UK, vol 227, pp 111-119

Arkhangelsky E, Levitsky I, Gitis V (2017) Considering energy efficiency in filtration of engineering nanoparticles. Water Supply 17:1212-1218

Buxton GV, Greenstock CL, Helman WP, Ross AB (1988) Critical review of rate constants for reactions of hydrated electrons, hydrogen atoms and hydroxyl radicals $\left(\cdot \mathrm{OH} / \cdot \mathrm{O}^{-}\right.$in aqueous solution. J Phys Chem Ref Data 17:513-886

Christou A, Karaolia P, Hapeshi E et al (2017) Long-term wastewater irrigation of vegetables in real agricultural systems: concentration of pharmaceuticals in soil, uptake and bioaccumulation in tomato fruits and human health risk assessment. Water Res 109:24-34

Clara M, Strenn B, Gans O et al (2005) Removal of selected pharmaceuticals, fragrances and endocrine disrupting compounds in a membrane bioreactor and conventional wastewater treatment plants. Water Res 39:4797-4807

Colborn T, vom Saal FS, Soto AM (1994) Developmental effects of endocrine-disrupting chemicals in wildlife and humans. Hum Health Environ Unansw Quest Unquest Answ 14:469-489

Darbre P (2015) Endocrine disruption and human health, 1st edn. Academic Press, Boston

Fenton H (1894) LXXIII.- oxidation of tartaric acid in presence of iron. J Chem Soc Trans 65:899-910

Gitis V, Rothenberg G (2016) Ceramic membranes: new opportunities and practical applications, 1st edn. Wiley, New York

Heberer T (2002) Tracking persistent pharmaceutical residues from municipal sewage to drinking water. Attenuation Groundw Pollut Bank Filtr 266:175-189

Horovitz I, Gitis V, Avisar D, Mamane H (2019) Ceramic-based photocatalytic membrane reactors for water treatment-where to next? Rev Chem Eng. https://doi.org/10.1515/revce-2018-0036

Huerta-Fontela M, Galceran MT, Ventura F (2011) Occurrence and removal of pharmaceuticals and hormones through drinking water treatment. Water Res 45:1432-1442 
Karnik BS, Davies SHR, Chen KC et al (2005) Effects of ozonation on the permeate flux of nanocrystalline ceramic membranes. Water Res 39:728-734

Keenan CR, Sedlak DL (2008) Factors affecting the yield of oxidants from the reaction of nanoparticulate zero-valent iron and oxygen. Environ Sci Technol 42:1262-1267

Kleywegt S, Pileggi V, Yang P et al (2011) Pharmaceuticals, hormones and bisphenol $\mathrm{A}$ in untreated source and finished drinking water in Ontario, Canada-occurrence and treatment efficiency. Sci Total Environ 409:1481-1488

Kritikaki A, Tsetsekou A (2009) Fabrication of porous alumina ceramics from powder mixtures with sol-gel derived nanometer alumina: effect of mixing method. J Eur Ceram Soc 29:1603-1611

Kwan WP, Voelker BM (2003) Rates of hydroxyl radical generation and organic compound oxidation in mineral-catalyzed fentonlike systems. Environ Sci Technol 37:1150-1158

Levitsky I, Dahan Y, Arkhangelsky E, Gitis V (2014) Retention of modified BSA by UF membranes. J Chem Technol Biotechnol 91(2):400-407

Li Q, Liu Z, Liu Q (2014) Kinetics of vanadium leaching from a spent industrial $\mathrm{V}_{2} \mathrm{O}_{5} / \mathrm{TiO}_{2}$ catalyst by sulfuric acid. Ind Eng Chem Res 53:2956-2962

Lindqvist K, Lidén E (1997) Preparation of alumina membranes by tape casting and dip coating. J Eur Ceram Soc 17:359-366

Luo Y, Guo W, Ngo HH et al (2014) A review on the occurrence of micropollutants in the aquatic environment and their fate and removal during wastewater treatment. Sci Total Environ 473-474:619-641

Lyckfeldt O, Ferreira JMF (1998) Processing of porous ceramics by 'starch consolidation'. J Eur Ceram Soc 18:131-140

Malato S, Fernández-Ibáñez P, Maldonado MI et al (2009) Decontamination and disinfection of water by solar photocatalysis: recent overview and trends. Monogr Decontam Disinfect Water Sol Photocatal Recent Overv Trends 147:1-59

Matamoros V, Bayona JM (2006) Elimination of pharmaceuticals and personal care products in subsurface flow constructed wetlands. Environ Sci Technol 40:5811-5816

Mizuno N, Kamata K (2011) Catalytic oxidation of hydrocarbons with hydrogen peroxide by vanadium-based polyoxometalates. In: Seventh international symposium on chem biol chem vanadium, vol 255, pp 2358-2370

Naim R, Levitsky I, Gitis V (2012) Surfactant cleaning of UF membranes fouled by proteins. Sep Purif Technol 94:39-43

Naim R, Epsztein R, Felder A et al (2014) Rethinking the role of in-line coagulation in tertiary membrane filtration of municipal effluents. Sep Purif Technol 125:11-20

Oliveira LCA, Coura CVZ, Guimarães IR, Gonçalves M (2011) Removal of organic dyes using Cr-containing activated carbon prepared from leather waste. J Hazard Mater 192:1094-1099

Ribeiro AR, Nunes OC, Pereira MFR, Silva AMT (2015) An overview on the advanced oxidation processes applied for the treatment of water pollutants defined in the recently launched Directive 2013/39/EU. Environ Int 75:33-51

Routledge EJ, Sheahan D, Desbrow C et al (1998) Identification of estrogenic chemicals in STW effluent. 2. In vivo responses in trout and roach. Environ Sci Technol 32:1559-1565
Schwab BW, Hayes EP, Fiori JM et al (2005) Human pharmaceuticals in US surface waters: a human health risk assessment. Regul Toxicol Pharmacol RTP 42:296-312

Song W, Huang M, Rumbeiha W, Li H (2007) Determination of amprolium, carbadox, monensin, and tylosin in surface water by liquid chromatography/tandem mass spectrometry. Rapid Commun Mass Spectrom 21:1944-1950

Stuart M, Lapworth D, Crane E, Hart A (2012) Review of risk from potential emerging contaminants in UK groundwater. Sci Total Environ 416:1-21

Sudhakaran S, Maeng SK, Amy G (2013) Hybridization of natural systems with advanced treatment processes for organic micropollutant removals: new concepts in multi-barrier treatment. Chemosphere 92:731-737

Szymczycha-Madeja A (2011) Kinetics of Mo, Ni, V and Al leaching from a spent hydrodesulphurization catalyst in a solution containing oxalic acid and hydrogen peroxide. J Hazard Mater $186: 2157-2161$

Tijani J, Fatoba O, Babajide O, Petrik L (2015) Pharmaceuticals, endocrine disruptors, personal care products, nanomaterials and perfluorinated pollutants: a review. Environ Chem Lett 14:27-49

Tixier C, Singer HP, Oellers S, Müller SR (2003) Occurrence and fate of carbamazepine, clofibric acid, diclofenac, ibuprofen, ketoprofen, and naproxen in surface waters. Environ Sci Technol 37:1061-1068

Tyler CR, Filby AL (2011) Feminized fish, environmental estrogens, and wastewater effluents in English Rivers. In: Elliott JE, Bishop CA, Morrissey CA (eds) Wildlife ecotoxicology: forensic approaches. Springer, New York, pp 383-412

Wyart Y, Georges G, Deumié C et al (2008) Membrane characterization by microscopic methods: multiscale structure. J Membr Sci 315:82-92

Yang WP, Shyu SS, Lee E-S, Chao A-C (1996) Effects of PVA content and calcination temperature on the properties of PVA/boehmite composite film. Mater Chem Phys 45:108-113

Zhang Y, Geißen S-U, Gal C (2008) Carbamazepine and diclofenac: removal in wastewater treatment plants and occurrence in water bodies. Chemosphere 73:1151-1161

Zhang S, Zhao X, Niu H et al (2009) Superparamagnetic $\mathrm{Fe}_{3} \mathrm{O}_{4}$ nanoparticles as catalysts for the catalytic oxidation of phenolic and aniline compounds. J Hazard Mater 167:560-566

Zhu B, Hu Y, Kennedy S et al (2011) Dual function filtration and catalytic breakdown of organic pollutants in wastewater using ozonation with titania and alumina membranes. Membr Sustain Future Sect 378:61-72

Zwiener C, Frimmel FH (2000) Oxidative treatment of pharmaceuticals in water. Water Res 34:1881-1885

Publisher's Note Springer Nature remains neutral with regard to jurisdictional claims in published maps and institutional affiliations. 


\section{Affiliations}

\section{Lev Tsapovsky ${ }^{1,2} \cdot$ Michal Simhon $^{1} \cdot$ Vincenzo Roberto Calderone ${ }^{2} \cdot$ Gadi Rothenberg $^{2} \cdot$ Vitaly Gitis $^{2,3}$ (I)}

1 Unit of Environmental Engineering, Faculty of Engineering Sciences, Ben-Gurion University of the Negev, PO Box 653 , 8410501 Beer-Sheva, Israel

2 Van 't Hoff Institute for Molecular Sciences, University of Amsterdam, Science Park 904, 1098 XH Amsterdam, The Netherlands
3 Unit of Energy Engineering, Faculty of Engineering Sciences, Ben-Gurion University of the Negev, PO Box 653, Beer-Sheva 8410501, Israel 